\title{
Characterization and Suitability Evaluation of Soils of a Toposequence at University of Agriculture Makurdi Teaching and Research Farm for the Production of Rice (Oryza sativa) in Makurdi, Benue State.
}

\author{
Abagyeh S. O. I., Idoga S. and Ibrahim F. \\ Department of Soil Science, Federal University of Agriculture, Makurdi, Nigeria. \\ Correspondence Author's E-mail: abacks1959@gmail.com
}

\begin{abstract}
A toposequence at University of Agriculture Makurdi Teaching and Research Farm, Benue state was detail surveyed to characterize, classify and assess the suitability of the soils for sustainable rice production. Critical land and soil requirements for rice production were related with data obtained from both field and laboratory studies. The results showed that the soils had sandy loam to clay textures; weak fine crumb to strong coarse subangular blocky structure and friable to very firm consistency. All pedons except 1 had redoximorphic properties. Soil reaction ranged from slightly (6.0) to moderately acid (5.0), organic carbon (0.18-.55\%). Total nitrogen and phosphorus were inadequate with low exchangeable cations and micro-nutrients. Pedon 1 was classified as Lithic Ustropept (Plinthic Cambisol (Eutric, Rhodic)) while 11 and 111 were keyed into Typic Plinthudalfs (Eutric, Plinthosols (Clayic, Greyic)). Land characteristics (mean annual rainfall, temperature, relative humidity, topography, coarse fragments and base saturation) were not major limitations for rice production however, there was no highly (S1) or moderately suitable (S2) land for rice cultivation. Productivity index (IPC) ranged between 3.10 and 10.08, and were thus currently not suitable for both upland and lowland rice cultivation by assessments of the two models. Linear model of IPp (17.55-21.06) for upland rice and (11.36) in pedon 1 for lowland rice, showed the soils were currently not suitable for rice cultivation but pedons 11 (29.25) and 111 (37.05) were marginally suitable for lowland rice cultivation. The square root model index of productivity had IPp of 21.77 in pedon 1, 26.12 in 11 and 28.37 in pedon 111. Thus, pedon 1 was currently not suitable; pedons 11 and 111 were marginally suitable for upland rice. Pedon 1 IPp (11.91) was currently not suitable whereas pedons 11 (36.79) and pedon 111 IPp (31.820) were marginally suitable for lowland rice cultivation. The soils' major
\end{abstract}

limitations were the low levels of macro and micronutrients. Management techniques including continuous organic matter incorporation and mineral fertilizers application to the land will adjust the soils structure and boast their fertility level.

Keywords- Characterization, Suitability, Toposequence, rice, productivity.

\section{INTRODUCTION}

Nigeria is the largest producer of rice in the West African sub region. This cereal crop constitutes a major source of calories not only for urban but the rural population with growth demand at 5\% annually. Unfortunately this demand has never been met by local production leading to huge rice importation with the balance of payment of over \$4 billion between 1991 and 1999 (Akande, 2008). The shortfall which may be due to low yielding rice varieties or low fertility levels of the soils among others calls for urgent need to boast local production. However, one of the problems confronting agricultural productivity in developing countries, Nigeria inclusive, is the ineffective and unplanned use of agricultural land. It is therefore imperative to apply land according to its potential suitability.

To date, the FAO guideline on the land evaluation system is widely accepted for soil evaluation. The system is based primarily on an integration of land qualities as related to individual crop requirements. The similar system developed by Sys et al (1993) reports the crop requirements based on the experiments/experience for the land in the tropics.

According to Fasina et al., (2007), the primary and most effective land conservation method is appropriate allocation of land to uses for which they are most suitable. Many studies related to various aspect of land suitability for crop cultivation have been conducted on the basis of 
FAO framework in different parts of Nigeria (Ajiboye $e t$ al., 2011; Hassan et al., (2002; Fasina et al., 2007). Elsewhere, there are records of researches conducted using the FAO framework for land evaluation (Sys et al., 1993; Storie, 1933; Van Lanen et al., 1992).

Although the multiplicative parametric approach may have been criticized as failing in considering the relative importance of relative stable soil properties capable of dominating crop performance in the determination of suitability classes, the proposed Fuzzy techniques also has some limitations that make its use practically difficult. The matching procedure in land evaluation could be by use of limiting conditions, arithmetic procedures, or modeling. It is apparent that some of these methodologies are subject to human bias. It is pertinent to emphasize that while value judgment is inevitable in any land evaluation exercise; there is nevertheless the need to explore strategies that are intuitively superior and take into cognizance the relative importance of differentiating characteristics to crop performance.

The following soil parameters; cation exchange capacity; soil organic matter content expressed by the organic carbon content, soil depth and stoniness are amongst the main factors that influence crop adaptability to a given land area. Some conservative farming practices could as well accelerate soil chemical and physical degradation and create some of the unfavourable soils.

\section{MATERIALS AND METHODS}

\section{The study area}

The study area lies between Latitude $07^{\circ} 44.693$ and $7^{\circ}$ $45.587 \mathrm{~N}$ and Longitude $008^{\circ} 37.437 \mathrm{E}$ and $008^{\circ} 37.483 \mathrm{E}$ covering an estimated area of 9 hectares. Topography is gently undulating with dominant slopes of between 0 and 5\%. Elevation varies between 99 and $123 \mathrm{~m}$ above mean surface level. The study sites have tropical subhumid climate characterized by high humidity (> 70\%). Annual rainfall ranges between 1220 and $1500 \mathrm{~mm}$ with annual maximum mean temperature ranging from $29.5-33^{\circ} \mathrm{C}$. The original semi-deciduous vegetation has been drastically disturbed by farming and timber logging resulting into secondary vegetation succession like bushregrowth; thick derived savannah has taken over the place. The type of land use is majorly arable cultivation in small holdings; major crops include maize, rice, sorghum, yam, cassava, vegetable, oil palm with fruit orchards scattered over the area. The study area has fine Awe and Makurdi sandstones (upland) of cretaceous sediment while lowland has alluvium-shale intercalation both, underlain by undifferentiated basement complex materials (Offodile, 2014).

\section{Field work}

An area of 9 hectares was chosen to represent the farming community. The major soil types were identified following the rigid grid soil survey method. Three profile pits were sunk and morphological characterization using the pattern outlined in the soil survey manual (Soil Survey Staff, 2010; Gutherie and Witty, 1982) was carried out. Soil samples were collected from identified profile horizons for laboratory analysis. Based on the morphological characteristics, the landscape segments were classified into two mapping units.

\section{Laboratory analysis}

Soil samples were air-dried, crushed and passed through a-2 $\mathrm{mm}$ sieve and analyzed using standard procedure. Soil particle size was determined by hydrometer method (Bouyoucos, 1962) with sodium hexameta-phosphate as the dispersing agent. Soil $\mathrm{pH}$ was determined by $\mathrm{pH}$ meter in water using a 1:1 soil/water ratio. Total Nitrogen was determined by Microkjeldah method. Organic carbon was determined by Walkley and Black dichromate wet oxidation method (Allison, 1965). Available phosphorus was determined by the ammonium molebdate blue method (Bray and Kurtz, 1945). Exchangeable cations ( $\mathrm{Ca}, \mathrm{Mg}, \mathrm{Na}$ and $\mathrm{K}$ ) were extracted with $1 \mathrm{~N}$ NH4OAC. PH 7.0 (ammonium acetate), $\mathrm{K}$ and $\mathrm{Na}$ were determined with flame emission photometer while $\mathrm{Ca}$ and $\mathrm{Mg}$ were determined with atomic absorption spectrophotometer. Exchangeable acidity was extracted wit h $1 \mathrm{~N} \mathrm{KCl}$ (Maclean, 1965). CEC was determined by leaching the soil with $1 \mathrm{~N}$ salt solution buffered at a given $\mathrm{pH}$ which was slightly higher than 7 . Effective cation exchange capacity (ECEC) was determined by summation of the exchangeable cations and the exchangeable acidity. Base saturation was calculated as sum of total exchangeable bases (TEB) divided by the CEC x 100.

\section{Soil Classification and Land Evaluation Procedure}

The Soils were classified according to the USDA Soil Taxonomy (Soil Survey Staff, 2010) and the World Reference Base (2006) classification systems.

The land evaluation was done using the parametric linear models (Storie, 1933) and the square root models (Ogunkule, 1993; Uddoh, 2008; Ajiboye, 2011) of the FAO (1976) framework. Pedons were placed in suitability classes by matching their characteristics/qualities (Table 2) with the established requirement for rice production (Table 1) following the ratings of the characteristics. The most limiting characteristic(s) in a group determine the performance of the pedon, hence the final (aggregate) suitability class.

The groups of land qualities considered for evaluation were climate $(\mathrm{c})$, topography $(\mathrm{t})$, drainage characteristics (w), soil physical characteristics (s) and soil chemical fertility (f). Soil fertility was assessed using soil reaction, macro and micro-nutrients levels. In computing the potential suitability for rice production, the fertility factors that can be amended by fertilizer applications and management practices (level of available macronutrients, 


\begin{abstract}
$\mathrm{N}, \mathrm{P}$ and $\mathrm{K}$ and organic matter content of the soil) were excluded. However, the soil CEC, percent base saturation and $\mathrm{pH}$ were considered.

The current suitability was computed linearly using index of current (actual) productivity (IPc) of Storie (1933):

$\mathrm{IPc}=\mathrm{A} \mathrm{X} \mathrm{B/100} \mathrm{X} \mathrm{C/100 \ldots .} \mathrm{X} \mathrm{F/100} \mathrm{\ldots ...} \mathrm{(i)}$

Where,

IPc is index of current actual productivity; $\mathrm{A}$ is the overall least rating characteristic and $\mathrm{B}, \mathrm{C} \ldots \mathrm{F}$ is the least rating characteristic for each land group quality.

The potential suitability IPp was similarly computed using the square root model as;

$\mathrm{IPp}=\mathrm{A} \sqrt{ }(\mathrm{B} / 100 \times \mathrm{C} / 100 \times \ldots \mathrm{F} / 100)$

Where $\sqrt{ }$ is square root, $A$ is the overall least rating characteristic and $\mathrm{B}, \mathrm{C} \ldots \mathrm{F}$ are the least rating characteristic for each land group quality.
\end{abstract}

\section{RESULTS AND DISCUSSION}

\section{Physical properties}

Table 2 presents the physical and morphological properties of the soils of the toposequence. Pedons 11 and 111 were deep and considered highly suitable while pedon 1 was shallow and moderately suitable for rice cultivation. However all the pedons had plinthite from the B horizon through to the subsoils. The redoximophic conditions of pedons 1 and 11 as indicated by the presence of few to common, fine to coarse, faint to distinct mottles occurring from $20-100 \mathrm{~cm}$ ) may be attributed to plinthite. These soils may not however, have been under permanent water saturation for a period longer than some few months as indicated by the soil colour which ranged from dark reddish brown (5YR3/4) through dull orange (5YR7/4) to grayish yellowish brown(10YR5/2). This condition is not considered as a limitation for rice cultivation.

The soil texture ranged from sandy loam to clay. Upland requires loamy soil while lowland rice requires loamy clay to sandy loamy clay for optimal performance. Thus, the toposequence presents soils with slight limitation to rice yield and were rated $65 \%$. The soil structures ranged between weak fine crumbs to coarse sub angular blocky which are appropriate for upland and lowland rice production respectively (Sys, 1993). The structures were highly suitable for upland and moderately suitable for lowland rice production.

\section{Chemical properties}

The soil chemical properties that could affect soil suitability for the cultivation of rice include acidity, salinity and fertility. The $\mathrm{pH}$ of the soil measured in water ranged from 5.48 to 5.95 , indicating a moderate acid reaction (James, 2010). This may not pose serious problem for phosphorus uptake and limit micronutrients ( $\mathrm{Fe}, \mathrm{Zn}, \mathrm{Cu}$ and $\mathrm{Mn}$ ) availability which form metallic cations that precipitate into low solubility compounds at high $\mathrm{pH}$ levels. Total exchangeable acidity (EA) ranged between 0.06 to $1.07 \mathrm{cmolkg}^{-1}$, an indication that exchangeable aluminum was still below toxic level.

The CEC of the soils were very low $\left(<16 \mathrm{cmolkg}^{-1}\right)$ and ranged from 4.45 to $6.12 \mathrm{cmolkg}^{-1}$. The relatively low values of cation exchange capacity (CEC) could be attributed to the low clay and organic matter contents, probably dominated by Kaolinite (Adesemuyi, 2014). The average values of CEC both at the surface and subsurface horizons increased downward the toposequence with the lower slope having the highest average values. Thus, with the relatively high rainfall intensity within the area, fertilizer application must be in several splits, though with increase cost of production, to avoid leaching. The low CEC values of these soils present a moderate limitation to rice cultivation. The soils have medium to high levels of exchangeable potassium, calcium and magnesium with very low levels of sodium, organic carbon, nitrogen and phosphorus (Bray 1). Most of the macronutrients (sodium, organic carbon, nitrogen and phosphorus) and the micronutrient, iron were lower than the critical requirements for rice cultivation. Thus, the greatest limitation to rice production is related to soil fertility status. This result is in agreement with the findings of Ajiboye et al., (2011) and Adesanwo (2002) who evaluated of soils in parts of Ogun state, Nigeria for rice production.

The result showed that iron deficiency rather than the expected toxicity in Nigeria was the limitation of these soils apart from sodium, organic carbon, nitrogen and phosphorus.

\section{Other qualities}

With the mean annual temperature of $33^{\circ} \mathrm{C}$, total annual rainfall and distribution of $>1200 \mathrm{~mm}$, solar radiation $13 \mathrm{mjcm}^{-2} \mathrm{~d}^{-1}$ and average relative humidity at cropping season of $71 \%$, the climate of the surveyed area is quite favourable for rice cultivation by Sys (1993). The topography of the toposequence with slope between 0 to $5 \%$ is considered adequate. The entire toposequence is well drained except during the rains when the middle and lower slope become saturated after heavy down pours and therefore, considered most suitable for lowland rice cultivation.

\section{Soil Classification}

UAM1pedon possesed neither an ochric epipedon, a petrocalcic horizon nor duripan, but had base saturation of above 50 per cent throughout its $0 \mathrm{~cm}$ to $50 \mathrm{~cm}$ profile depth. It also displayed an irregular clay distribution with a weak B-horizon (Cambic horizon), formed under typical tropical climatic conditions with heavy rainfall and somewhat extreme temperatures with ustic soil moisture regime. It possessed one or more horizon within $100 \mathrm{~cm}$ of the mineral soil surface in which plinthic material forms a continuous phase or constitutes one half or more of the 
volume. The soil pedons therefore qualified at the subgroup level as Lithic Ustropept (Plinthic Cambisol (Eutric, Rhodic)).

Pedons UAM11and 111 have argillic horizons as evidence by the presence of clay cutans. They also possessed base saturation of more than 70 per cent (by $\mathrm{NH}_{4} \mathrm{OAc}$ at $\mathrm{pH}$ 7.0) throughout the entire profile depths while Udic soil moisture regime has been inferred for the soils, The soils are dark brown to grey but not dark red or dull red; they possessed no petrocalcic horizon within $1.5 \mathrm{~m}$ but gradual and clear smooth but not abrupt upper boundaries of argillic horizons. They had no nitric horizon or duripan but plinthic materials and are provisionally classified into Typic Plinthudalfs (Lixic Plinthosols (Eutric, Clayic))

\section{Evaluation Soils for rice cultivation}

Suitability ratings of the pedons characteristics (Table 4 ) were obtained by comparing their values (Tables 2 and 3 ) with the land requirements for upland and lowland rice (Table 1 ) using the ratings for the limited characteristics in Table 1. Aggregate suitability ratings (potential and actual) were computed using the linear and square root parametric models.

Most of the macronutrients (sodium, organic carbon, nitrogen and phosphorus) and iron were lower than the critical requirements for rice cultivation except exchangeable potassium contents that ranged 0.19 to .0 .36 $\mathrm{cmolkg}^{-1}$. All pedons had index of current productivity (IPc) of less than 12.5 and were classified as permanently not suitable (N2) for both upland and lowland rice cultivation according to linear and square root models assessments (Tables 4). The major limiting factors were the low levels of available macronutrients and iron. The evaluation of the potential suitability of the soils without considering the levels of organic carbon, macro- and micronutrients regarded as temporary limitations using linear model indicated that all pedons had index of potential productivity (IPp) of less than 25.0 and are currently not suitable for upland and 11.36 in pedon 1 but 29.25 - 37.05 in pedons 11 and 111 for lowland rice, therefore pedon 1 is permanently not suitable (N2) while pedons 11 and 111 were marginally suitable for it cultivation.

Under the square root model of assessment, pedons 1 and 11 (IPp > 25) were marginally suitable (S3) while pedon 111 (IPp <25) was currently not suitable (N1) for upland rice. Pedons 11 and 111 (IPp .25.0) were marginally suitable (S3) and pedon 1 (IPp <12.5) was permanently not suitable (N2) for lowland rice cultivation (Table 4). The major limitations of the soils for up and lowland rice cultivation were the low levels of macro and micronutrient $(\mathrm{Fe})$.

These deficiencies of the macronutrients (OC and available phosphorus) must be remedied if optimal rice production is to be achieved in the toposequence and indeed Nigeria is to be achieved. Therefore, there is need for fertilizer application strategies beyond mineral fertilizer application while fertility management techniques should be in tune with the diverse farming systems and must include crop rotation, plant residue recycling and organic agriculture as well as rapid grain legume fallowing (mucuna).

Rice is sensitive to micronutrients with iron as most limiting micronutrient limiting rice growth and yield by this study. Generally, $\mathrm{Zn}, \mathrm{Fe}$ and $\mathrm{Mn}$ are most common on neutral and calcareous soil, intensively cropped soils, paddy and poorly drained soils (Ajiboe et al., 2011). Fertilizer recommendation for rice cultivation in many African countries often neglects the importance of these nutrients in achieving good yield. According to Ajiboy et al., (2011), Africa Rice Centre Cotonu Benin accepted the possibility of iron and zinc deficiencies occurring between 1-2 and 3-4 weeks after seedling emergence respectively. The Centre recommended the application of foliar spray of ferrous sulphate or zinc sulphate only as corrective measure. Unfortunately, the current research underscored the need to assess the micronutrient status of the major rice growing area if the country will realize increase per hectare output of rice needed to achieve self sufficiency in rice production. Despite apparent deficiency of $\mathrm{N}$ and $\mathrm{P}$ in these soils, the present system recommendation (FDPP, 1989) would have corrected these deficiencies without increase in rice yield due to the neglected micronutrient deficiencies. To avoid over application of these micronutrients that may lead to toxicity, the use of organic and green manures have been suggested in India (Ajiboye, et al., 2011).

This study opined however that, a suitable combination of organic and inorganic fertilizer at appropriate rates after laboratory and field studies will be of tremendous importance in solving the problem of low fertility soils for rice production in Nigeria.

\section{REFERENCE}

[1] Adesemuyi, E.A. (2014). Suitability Assessment of Soils for Maize (Zea Mays) Production in a Humid Tropical Area of South-Western Nigeria. International Journal of Advanced Research (2014), Volume 2, Issue 2, 538-546

[2] Adesanwo A. (2002). Dettermination of productivity levels among rice farmers from Obafemi-Owode LGA of Ogun State. In Proceedings of NISER/WARDA Nigeria Rice Economy stake holder workshop. Bouke, Cote d'Ivoire.103Pp.

[3] Ajiboy, G. A., Alabi K. O., Aiboni, V. U., Okeleye, K. A. and Adesodun, J. K. (2011). Classification and suitability evaluation of the soils of a toposequence 
at UAMTRF Benue State for the cultivation of rice (Oryza sativa). NJSS 21(1) .....

[4] Akande, T. (2008). An over view of the Nigeria rice economy. The Nigeria Institute of Social and Economic Research (NISER), Ibadan, Nigeria, $11 \mathrm{Pp}$.

[5] Allison, L. E. 1965. Methods of Soil Analysis. Agron. 9. American Society of Agronomists. Medison, Wisconsin. Pp1367-1378.

[6] Bouyoucos G.H. 1951. A recalibration of the Hydrometer for making mechanical Analysis J. 43434-438.

[7] Bray, R.H, Kurtz L.T. 1945. Determination of Total Organic and Available Forms

[8] FAO (1976). A Framework for Land Evaluation. FAO Soils Bull ,32: FAO, Rome, 87pp.

[9] Fasina, A. S, Omolayo, F. O.Ajayi, O. S. and Falodun, A. A. (2007). Influence of land use on soil properties of the three mapping units in Southwestern Nigeria - Implication for soil management. Research Journal of Applied Sciences, 2(8): $879-883$.

[10] Gutherie R.L and Witty, I. 1982. New designation for soil horizons and layers and the New Soil Survey manual. Soil Science Society of America Journal. 46:443-444.

[11] Hassan, M., Lilienthal, H. and Schnug, E. (2002). Evaluation of land suitability for agriculture in ElSalam region of North Siai. Federal Agricultural Centre (FAL). Institute of Plant Nutrition and Soil Science, Germany.

[12] James R. 2010. Irrigation Water Greenhouses and Nurseries. University Arkansas, Division of Agriculture, Agriculture and Natural Resources.
[13] Offdile, M.E. 2014.Hydrogeology: Ground water study and development in Nigeria. $3^{\text {rd }} \mathrm{Ed}$.

[14] Ogunkule, A. O. (1993). Soil in land suitability evaluation : an example with oil palm in Nigeria. Soil Use and Management 9:37-42.

[15] Soil Survey Staff 2010. Key to Soil Taxonomy, 11 Edition. Basic System of Soil Classification for Making and Interpreting Soil Survey, National Reserve Conservation Services, Agricultural Departmen, Soil Survey Division. Washingston DC USA

[16] Storie, R. E. (1933). An index for rating the agricultural value of soils. Bulletin - California Agricultural Experiment Station 556, University of California Agricultural Experiment Station, Berkley, CA.

[17] Sys, C., Ranst,V., Debaveye, J., and Beeraert, F. (1993).Land Evaluation Part 111, crop requirements. Agricultural publication No. 7, ITC Ghent. 199p.

[18] Uddoh, T. B. (2008). Soil texture and fertility constraint in land suitability for Oil-Palm cultivation in a humid tropical climate of Akwa Ibom State, Nigeria. Nigeria Journal Soil Science 18: 175-182

[19] Van Lanen H. A. J., Hack-Ten Broeke, M. J. D., Bouma, J. and DeGroot, W. J. M. (1992). Amixed qualitative /quantitative physical land evaluatyion methodology. Geoderma 55; 37- 54

[20] World Reference Base (2006). World reference base for soil sources, 2006 edition. A frame work for international classification, correlation and communication. FAO United Nations, Rome.

Table.1: Land Requirements for Suitability Classes for Upland and Lowland Rice Cultivation

\begin{tabular}{|c|c|c|c|c|c|c|c|}
\hline \multirow{2}{*}{ Land Qualities } & Rate & $95-100$ & $70-94$ & $55-69$ & $40-54$ & $20-39$ & 0.00-19 \\
\hline & Class & S1 1 & $\mathbf{S 1}_{2}$ & S2 & S3 & N1 & N2 \\
\hline Climate & c & & & & & & \\
\hline $\begin{array}{l}\text { Mean Annual } \\
\text { Rainfall }\end{array}$ & $\mathrm{mm}$ & $>1000$ & $900-1000$ & $\begin{array}{c}800- \\
900\end{array}$ & $600-800$ & $500-600$ & $<500$ \\
\hline $\begin{array}{l}\text { Mean Annual } \\
\text { Max. Temp. }\end{array}$ & ${ }^{\circ} \mathrm{C}$ & $>25$ & $22-25$ & $20-22$ & $18-20$ & $16-18$ & $<16$ \\
\hline $\begin{array}{l}\text { Relative } \\
\text { Humidity }\end{array}$ & $\%$ & $>75$ & $70-75$ & $65-70$ & $60-65$ & $<60$ & - \\
\hline Topography & $\mathbf{t}$ & & & & & & \\
\hline Slope & $\%$ & $<2$ & $3-4$ & $5-6$ & $7-8$ & -10 & $>10$ \\
\hline Drainage & $\mathbf{w}$ & & & & & & \\
\hline Wetness & & WD (ID)* & $\begin{array}{l}\text { MWD } \\
\text { (ID)* }\end{array}$ & MD & ID $(\mathrm{WD}) *$ & $\mathrm{PD}(\mathrm{WD})^{*}$ & $\begin{array}{c}\mathrm{PD} \\
\text { (WD)* }\end{array}$ \\
\hline Flooding & & F0 & F0 & $\mathrm{F} 1$ & $\mathrm{~F} 1$ & $\mathrm{~F} 2$ & F3 \\
\hline $\begin{array}{l}\text { Soil Physical } \\
\text { Properties }\end{array}$ & $\mathbf{S}$ & & & & & & \\
\hline Texure & & $\mathrm{L}(\mathrm{LC})^{*}$ & $\begin{array}{c}\text { Lfs } \\
(\mathrm{SLC})^{*}\end{array}$ & $\begin{array}{l}\mathrm{LS} \\
(\mathrm{SL})^{*}\end{array}$ & S & $S$ & S \\
\hline
\end{tabular}




\begin{tabular}{|c|c|c|c|c|c|c|c|}
\hline Structure & & $\begin{array}{c}\mathrm{Cr} \\
(\mathrm{SAB})^{*}\end{array}$ & $\mathrm{Cr}(\mathrm{SAB}) *$ & $\begin{array}{l}\text { SAB } \\
(\mathrm{Cr})^{*}\end{array}$ & $\mathrm{SAB}(\mathrm{Cr})^{*}$ & $\mathrm{Col}(\mathrm{Cr})^{*}$ & $\mathrm{Col}(\mathrm{Cr})^{*}$ \\
\hline Coarse & $\%$ & $<3$ & $3-5$ & $5-10$ & $10-15$ & $>15$ & - \\
\hline $\begin{array}{l}\text { Fragments } \quad(0- \\
50 \mathrm{~cm})\end{array}$ & & & & & & & \\
\hline Soil Depth & $\mathrm{s}$ & $>75$ & $65-70$ & $50-65$ & $35-50$ & $30-35$ & $<30$ \\
\hline Soil Fertiliy & $\mathbf{f}$ & & & & & & \\
\hline $\mathrm{pH}$ & water & $5.5-6.5$ & $5.0-5.5$ & $4.5-5.0$ & $4.0-4.5$ & $<4.0$ & \\
\hline CEC & $\begin{array}{l}\text { (cmolkg-1 } \\
\text { clay) }\end{array}$ & $>16.0$ & $12-16.0$ & $8-12.0$ & $5.0-8.0$ & $<5.0$ & - \\
\hline Base Saturation & $\%$ & $>80$ & $70-80$ & $50-70$ & $40-50$ & $25-35$ & $<25$ \\
\hline \multicolumn{8}{|l|}{$\begin{array}{l}\text { Macro- } \\
\text { nutrients }\end{array}$} \\
\hline Nitrogen & $\%$ & $>2.0$ & $1.5-2.0$ & $1.0-1.5$ & $0.5-1.0$ & $<0.5$ & \\
\hline Avail. P & $\mathrm{mgkg}^{-1}$ & $>20$ & $15-20$ & $8-15$ & $5-8$ & $3-5$ & $<3$ \\
\hline Exractable $\mathrm{K}$ & cmolkg-1 $^{-1}$ & $>0.50$ & $0.3-0.5$ & $\begin{array}{c}0.20- \\
0.30\end{array}$ & $0.10-0.20$ & $<0.1$ & \\
\hline $\begin{array}{l}\text { Micro- } \\
\text { nutrients }\end{array}$ & $0.5 \mathrm{NHCl}$ & & & & & & \\
\hline Iron & $\mathrm{mgkg}^{-1}$ & $>4.5$ & $3.5-4.4$ & $2.5-3.5$ & $1.5-2.5$ & $1.0-1.5$ & $<1.0$ \\
\hline Zinc & ، & $2.0-2.5$ & $1.5-2.0$ & $1.0-1.5$ & $0.8-1.0$ & $0.6-0.8$ & $<0.6$ \\
\hline $\mathrm{Mn}$ & ، & $1.5-1.7$ & $1.0-1.5$ & $0.8-1.0$ & $0.6-0.8$ & $0.5-0.6$ & $<0.5$ \\
\hline
\end{tabular}

Source: Sys et al., (1993); Ajiboye et al., (2011)

Key: * = Ratings for lowland rice production: SAB - Subangular blocky, Col. - Columnar, Cr - Crumb; WD - Well drained, MWD - Moderately well drained, ID - Imperfectly drained, PD - Poorly drained; L - Loam, SL - Sandy loam, LS - Loamy sand, Lfs - Loamy fine sand, SCL - Sandy clay loam and C - Clay; F0 - Rarely Flooded, F1 - Flooding Expected, F2 - Irregularly Flooded and F3 - Regularly Flooded; C - Clay, CL - Clay Loam, LS - Loamy Sand, SL - Sandy Loam, LCS- Loamy Clay Sand, CS-ClayS and, S-Sand.

Table.2: Morphological / Physical Properties of Soils of a Toposequence at University of Agriculture Makurdi Teaching and Research Farm.

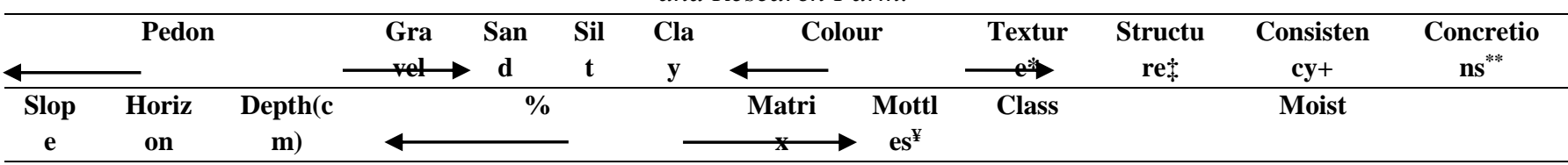

Up Ap $\quad 0-2$

$31-50$

11

$\begin{array}{lllllll}\text { Ap } & 0-20 & 9.3 & 65 . & 21 . & 13 . & 5 \text { YR3/ } \\ & & & 7 & 1 & 2 & 3 \\ \text { AB } & 20-38 & 11.4 & 61 . & 19 . & 18 . & 5 \text { YR6/ } \\ & & & 6 & 6 & 5 & 6\end{array}$

Bvt $_{1}$

$\begin{array}{llllll}12.9 & 71 . & 17 . & 10 . & 2.5 \mathrm{YR} \\ & 7 & 8 & 5 & 3 / 2 \\ 13.4 & 81 . & 10 . & 8.1 & 10 \mathrm{YR} 4 \\ & 4 & 5 & & / 4 \\ 21.6 & 77 . & 9.2 & 13 . & 5 \mathrm{YR} 3 /\end{array}$

$\begin{array}{lll}16.0 & 76 . & 12 . \\ & & \end{array}$

$\begin{array}{lll}9 & 5 & 5\end{array}$

SL $\quad 1 f-c c r \quad$ Vfr

SL 2f-csbk F

SL $\quad 3 f-c s b k \quad F$ 2
SL $\quad 1 f-m c r \quad V f r$

$1 \mathrm{mft}$ 10R4/ $2 \mathrm{md}$ 10R5/ 6

\begin{tabular}{|c|c|c|c|c|}
\hline- & SL & $1 \mathrm{f}-\mathrm{mcr}$ & Vfr & - \\
\hline $\begin{array}{l}1 \mathrm{mft} \\
10 \mathrm{R} 4 / \\
2\end{array}$ & SL & $1 \mathrm{f}-\mathrm{csbk}$ & $\mathrm{Fr}$ & $\begin{array}{l}\mathrm{Fe}-\mathrm{Mn}, \mathrm{c}, \\
\mathrm{r}\end{array}$ \\
\hline $\begin{array}{l}2 \mathrm{md} \\
10 \mathrm{R} 5 / \\
6\end{array}$ & SCL & $2 \mathrm{f}-\mathrm{cgr}$ & F & $\begin{array}{ll}\text { Fe- } & \text { Mn, } \\
\text { m; } & \text { Qtz }\end{array}$ \\
\hline
\end{tabular}




\begin{tabular}{|c|c|c|c|c|c|c|c|c|c|c|c|c|}
\hline & Bvt $_{2}$ & $64-100$ & 19.0 & $\begin{array}{l}45 . \\
9\end{array}$ & $\begin{array}{l}17 . \\
8\end{array}$ & $\begin{array}{l}36 . \\
34\end{array}$ & $\begin{array}{l}\text { 5YR7/ } \\
4\end{array}$ & $\begin{array}{l}2 \mathrm{md} \\
10 \mathrm{YR} \\
7 / 8\end{array}$ & $\mathrm{SC}$ & $3 \mathrm{csbk}$ & $\mathrm{F}$ & $\begin{array}{l}\mathrm{Fe}-\mathrm{Mn}, \mathrm{c} ; \\
\text { Qtz stones, } \\
\mathrm{f}\end{array}$ \\
\hline & & $\mathrm{M}$ & 13.6 & $\begin{array}{l}57 . \\
3\end{array}$ & $\begin{array}{l}18 . \\
7\end{array}$ & $\begin{array}{l}24 . \\
0\end{array}$ & & & & & & \\
\hline & 111 & & & & & & & & & & & \\
\hline \multirow[t]{5}{*}{$\begin{array}{l}\text { Low } \\
\text { er }\end{array}$} & Ap & $0-20$ & 6.4 & $\begin{array}{l}65 . \\
9\end{array}$ & $\begin{array}{l}19 . \\
1\end{array}$ & $\begin{array}{l}15 . \\
0\end{array}$ & $\begin{array}{l}5 Y R 3 / \\
4\end{array}$ & - & SL & $1 \mathrm{f}-\mathrm{mcr}$ & $\mathrm{Fr}$ & $\mathrm{Fe}-\mathrm{Mn}, \mathrm{f}, \mathrm{r}$ \\
\hline & $\mathbf{A B}$ & $20-29$ & 8.8 & $\begin{array}{l}61 . \\
9\end{array}$ & $\begin{array}{l}17 . \\
9\end{array}$ & $\begin{array}{l}20 . \\
2\end{array}$ & $\begin{array}{l}7.5 \mathrm{YR} \\
5 / 4\end{array}$ & $\begin{array}{l}2 \mathrm{fft} ; \\
10 \mathrm{YR} \\
7 / 8\end{array}$ & SCL & $2 \mathrm{f}-\mathrm{mcr}$ & $\mathrm{F}$ & $\begin{array}{l}\mathrm{Fe}-\mathrm{Mn}, \mathrm{c}, \\
\mathrm{f}\end{array}$ \\
\hline & Bvt $_{1}$ & $29-39$ & 20.3 & $\begin{array}{l}54 . \\
7\end{array}$ & $\begin{array}{l}15 . \\
6\end{array}$ & $\begin{array}{l}29 . \\
7\end{array}$ & $\begin{array}{l}\text { 10YR5 } \\
13\end{array}$ & $\begin{array}{l}2 \mathrm{md} ; \\
10 \mathrm{YR} \\
7 / 8\end{array}$ & SCL & $\begin{array}{l}2 \mathrm{f}- \\
\mathrm{csbk}\end{array}$ & $\mathrm{F}$ & $\begin{array}{l}\text { Fe- } \quad \mathrm{Mn}, \\
\mathrm{m} ; \quad \mathrm{Qtz} \\
\text { stones, f; }\end{array}$ \\
\hline & Bvt $_{2}$ & $39-95$ & 11.6 & $\begin{array}{l}42 . \\
4\end{array}$ & $\begin{array}{l}14 . \\
0\end{array}$ & $\begin{array}{l}43 . \\
6\end{array}$ & $\begin{array}{l}\text { 10YR5 } \\
/ 2\end{array}$ & $\begin{array}{l}\text { 3md; } \\
10 \mathrm{YR} \\
7 / 8\end{array}$ & $\mathrm{C}$ & $3 f-c s b k$ & Vf & $\begin{array}{l}\mathrm{Fe}-\quad \mathrm{Qtz} \\
\text { gravels, }\end{array}$ \\
\hline & & $\mathrm{M}$ & 11.8 & $\begin{array}{l}56 . \\
2\end{array}$ & $\begin{array}{l}16 . \\
7\end{array}$ & $\begin{array}{l}27 . \\
1\end{array}$ & & & & & & \\
\hline
\end{tabular}

Key: $*-\mathrm{C}=$ Clay, $\mathrm{SC}=$ Sandy Clay, $\mathrm{SCL}=$ Sandy Clay Loam and SL $=$ Sandy Loam,$+-1=\mathrm{f}=$ friable, fr $=$ firm, $\mathrm{vf}=$ very friable and $\mathrm{vfr}=$ very firm, $* *-\mathrm{Fe}=\mathrm{Iron}, \mathrm{Mn}=$ Manganese, $\mathrm{c}=$ common, $\mathrm{f}=\mathrm{few}, \mathrm{m}=$ many, $\mathrm{r}=$ round, $\mathrm{Qtz}=$ quartz , $\neq-1=$ weak, $2=$ moderate, $3=$ strong; $\mathrm{f}=$ fine, $\mathrm{m}=$ medium, $\mathrm{c}=$ coarse $; \mathrm{cr}=$ crumb, $\mathrm{gr}=$ granular and sbk = subangular blocky, $¥-1=$ few, 2 = common, $3=$ many; $\mathrm{f}=$ fine, $\mathrm{m}=$ medium, $\mathrm{c}=$ coarse; $\mathrm{ft}=$ faint, $\mathrm{d}=$ distinct, $\mathrm{p}=$ prominent.

Table.3: Chemical Characteristics of Pedons at the Toposequence of University of Agriculture Makurdi Teaching and Research Farm, Makurdi.

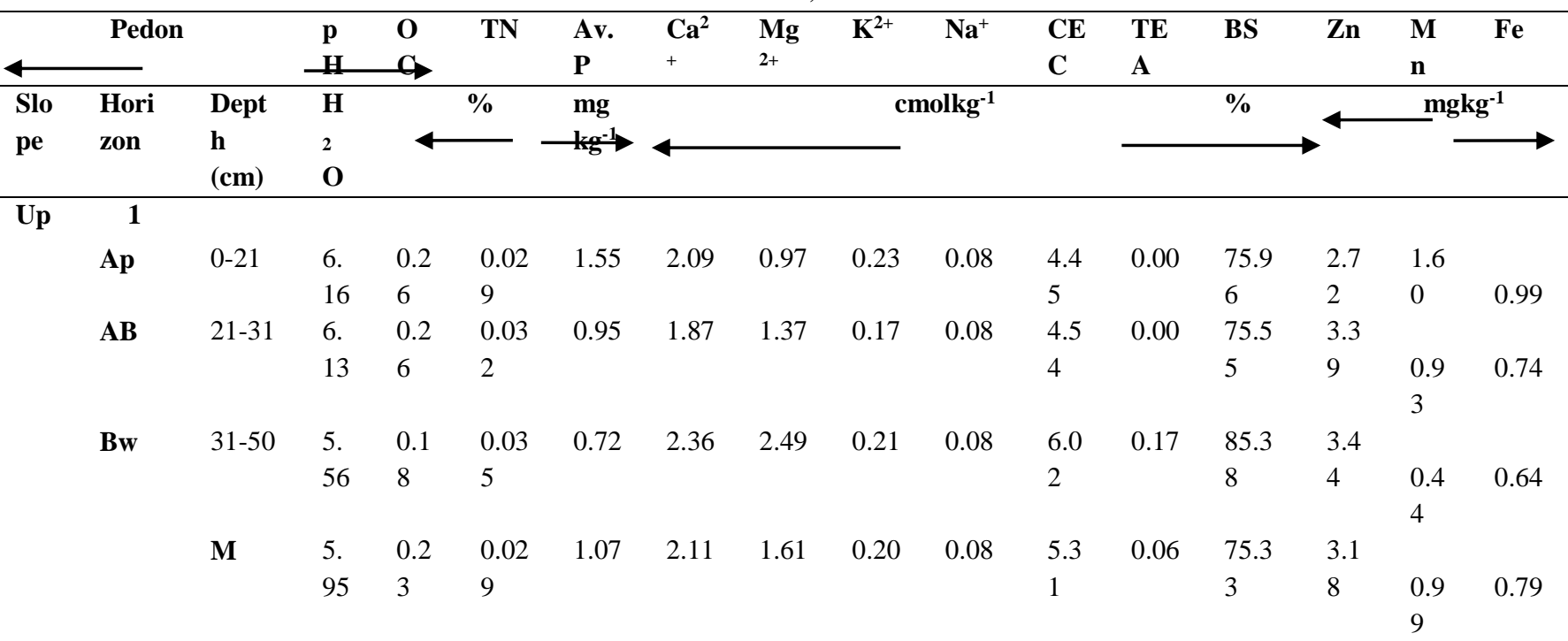

Mid 11

\begin{tabular}{|c|c|c|c|c|c|c|c|c|c|c|c|c|c|c|c|}
\hline \multirow[t]{2}{*}{ Ap } & $0 \quad-$ & 6. & 0.5 & 0.04 & 1.62 & 3.21 & 1.01 & 0.15 & 0.08 & 5.4 & 1.01 & 81.8 & 3.1 & 1.8 & 1.62 \\
\hline & 20 & 08 & 5 & 0 & & & & & & 4 & & 0 & 7 & 7 & \\
\hline \multirow[t]{2}{*}{$A B$} & $20-38$ & 5. & 0.4 & 0.03 & 1.45 & 3.28 & 2.14 & 0.21 & 0.09 & 6.5 & 2.18 & 87.8 & 3.3 & 1.1 & 1.18 \\
\hline & & 73 & 3 & 3 & & & & & & 1 & & 6 & 2 & 9 & \\
\hline \multirow[t]{2}{*}{ Bvt ${ }_{1}$} & $38-64$ & 5. & 0.3 & 0.03 & 0.90 & 2.14 & 2.06 & 0.22 & 0.08 & 5.8 & 0.76 & 76.7 & 3.9 & 0.9 & 1.11 \\
\hline & & 54 & 9 & 1 & & & & & & 6 & & 9 & 0 & 8 & \\
\hline \multirow[t]{4}{*}{ Bvt $_{2}$} & 64- & 5. & 0.2 & 0.02 & 1.29 & 2.11 & 1.49 & 0.19 & 0.08 & 6.6 & 0.31 & 58.1 & 3.5 & 0.8 & 1.03 \\
\hline & 100 & 41 & 3 & 7 & & & & & & 6 & & 1 & 5 & 8 & \\
\hline & $\mathbf{M}$ & 5. & 0.4 & 0.03 & 1.32 & 2.69 & 1.52 & 0.19 & 0.08 & 6.1 & 1.07 & 75.9 & 3.4 & 1.2 & 1.23 \\
\hline & & 69 & 0 & 3 & & & & & & 2 & & 4 & 8 & 3 & \\
\hline
\end{tabular}

Low 111

er
Ap

$0-$
20
$\begin{array}{ll}5 . & 0.4 \\ 60 & 5\end{array}$
0.04
$1.60 \quad 4.10$
2.20
0.31
0.1
7.8
4
1.00
85.8
$2.9 \quad 2.0$ 


\begin{tabular}{|c|c|c|c|c|c|c|c|c|c|c|c|c|c|c|c|}
\hline \multirow[t]{2}{*}{$\mathbf{A B}$} & $20-29$ & 5. & 0.4 & 0.04 & 1.48 & 4.80 & 2.60 & 0.42 & 0.10 & 8.4 & 0.40 & 93.8 & 3.5 & 1.0 & 1.26 \\
\hline & & 45 & 5 & 3 & & & & & & 4 & & 4 & 2 & 9 & \\
\hline \multirow[t]{2}{*}{ Bvt $_{1}$} & $29-39$ & 5. & 0.3 & 0.02 & 0.89 & 3.83 & 2.60 & 0.37 & 0.11 & 7.8 & 0.80 & 88.5 & 3.9 & 1.0 & 1.31 \\
\hline & & 56 & 9 & 8 & & & & & & 0 & & 9 & 9 & 8 & \\
\hline \multirow[t]{4}{*}{ Bvt $_{2}$} & $39-95$ & 5. & 0.2 & 0.02 & 1.32 & 3.11 & 1.81 & 0.35 & 0.11 & 6.4 & 0.67 & 83.2 & 3.7 & 0.6 & 1.23 \\
\hline & & 54 & 8 & 7 & & & & & & 6 & & 8 & 0 & 8 & \\
\hline & $\mathbf{M}$ & 5. & 0.3 & 0.03 & 1.32 & 3.96 & 2.30 & 0.36 & 0.11 & 7.6 & 1.00 & 87.8 & 3.5 & 1.2 & 1.36 \\
\hline & & 54 & 9 & 5 & & & & & & 4 & & 9 & 2 & 3 & \\
\hline
\end{tabular}

Key: TN - Total Nitrogen and Av. P = Available Phosphorus

Table.4: Suitability Ratings of Pedons Characteristics for Upland and Lowland Rice Cultivation at the Toposequence of University of Agriculture Makurdi Teaching and Research Farm, Makurdi.

\begin{tabular}{|c|c|c|c|c|c|c|c|}
\hline \multirow{2}{*}{$\begin{array}{l}\text { Land/Soil Xtics. } \\
\text { Pedon }\end{array}$} & \multirow[t]{2}{*}{ Unit } & \multicolumn{3}{|c|}{ Upland Rice } & \multicolumn{3}{|c|}{ Lowland Rice } \\
\hline & & 1 & 11 & $11 \overline{1}$ & 1 & 11 & $\overline{111}$ \\
\hline Climate & c & & & & & & \\
\hline $\begin{array}{l}\text { Mean Annual } \\
\text { Rainfall }\end{array}$ & $\mathbf{m m}$ & $100=\mathrm{S} 1$ & $100=\mathrm{S} 1$ & $100=\mathrm{S} 1$ & $100=\mathrm{S} 1$ & $100=\mathrm{S} 1$ & $100=\mathrm{S} 1$ \\
\hline $\begin{array}{l}\text { Mean Annual } \\
\text { Max. Temp. }\end{array}$ & ${ }^{\mathbf{o}} \mathbf{c}$ & $100=S 1$ & $100=\mathrm{S} 1$ & $100=\mathrm{S} 1$ & $100=\mathrm{S} 1$ & $100=S 1$ & $100=\mathrm{S} 1$ \\
\hline $\begin{array}{l}\text { Relative } \\
\text { Humidity }\end{array}$ & $\%$ & $100=\mathrm{S} 1$ & $100=\mathrm{S} 1$ & $100=\mathrm{S} 1$ & $100=\mathrm{S} 1$ & $100=\mathrm{S} 1$ & $100=\mathrm{S} 1$ \\
\hline Topography & $\mathbf{t}$ & & & & & & \\
\hline Slope & $\%$ & $85=\mathrm{S} 1_{2}$ & $100=\mathrm{S} 1$ & $100=\mathrm{S} 1$ & $85=S 1_{2}$ & $100=\mathrm{S} 1$ & $100=\mathrm{S} 1$ \\
\hline Drainage & $\mathbf{w}$ & & & & & & \\
\hline Wetness & & $100=\mathrm{S} 1$ & $54=\mathrm{S} 3$ & $54=\mathrm{S} 3$ & $54=\mathrm{S} 3$ & $95=\mathrm{S} 1$ & $95=\mathrm{S} 1$ \\
\hline Flooding & & $100=\mathrm{S} 1$ & $100=\mathrm{S} 1$ & $90=\mathrm{S} 1_{2}$ & $100=\mathrm{S} 1$ & $100=\mathrm{S} 1$ & $90=\mathrm{S} 1_{2}$ \\
\hline Soil Phy, Prop. & $\mathbf{S}$ & & & & & & \\
\hline Texure & class & $65=\mathrm{S} 2$ & $65=\mathrm{S} 2$ & $85=\mathrm{S} 1_{2}$ & $65=\mathrm{S} 2$ & $85=\mathrm{S} 1_{2}$ & $85=\mathrm{S} 1_{2}$ \\
\hline Structure & & $100=\mathrm{S} 1$ & $80=\mathrm{S} 1_{2}$ & $80=\mathrm{S} 1_{2}$ & $65=S 2$ & $65=S 2$ & $65=S 2$ \\
\hline $\begin{array}{l}\text { Coarse Frag. } \\
(0-50 \mathrm{~cm})\end{array}$ & $\%$ & $45=\mathrm{S} 3$ & $65=S 2$ & $65=\mathrm{S} 2$ & $45=\mathrm{S} 3$ & $65=S 2$ & $65=\mathrm{S} 2$ \\
\hline Soil Fertiliy & $\mathbf{f}$ & & & & & & \\
\hline CEC & cmolkg $^{-1}$ & $55=\mathrm{S} 2$ & $60=S 2$ & $50=\mathrm{S} 3$ & $55=\mathrm{S} 2$ & $60=S 2$ & $50=\mathrm{S} 3$ \\
\hline Base Saturation & $\%$ & $80=\mathrm{S}_{2}$ & $80=S 1_{2}$ & $80=\mathrm{S} 1_{2}$ & $80=\mathrm{S} 1_{2}$ & $80=S 1_{2}$ & $80=\mathrm{S} 1_{2}$ \\
\hline pH & $\mathrm{H}_{2} \mathrm{O}$ & $100=\mathrm{S} 1$ & $100=\mathrm{S} 1$ & $100=\mathrm{S} 1$ & $100=\mathrm{S} 1$ & $100=\mathrm{S} 1$ & $100=\mathrm{S} 1$ \\
\hline $\begin{array}{l}\text { Avail. P } \\
\text { Macro-nuts }\end{array}$ & mgkg $^{-1}$ & $15=\mathrm{N} 2$ & $20=\mathrm{N} 2$ & $20=\mathrm{N} 2$ & $15=\mathrm{N} 2$ & $20=\mathrm{N} 2$ & $20=\mathrm{N} 2$ \\
\hline Nitrogen & $\%$ & $20=\mathrm{N} 1$ & $30=\mathrm{N} 1$ & $30=\mathrm{N} 1$ & $25=\mathrm{N} 1$ & $30=\mathrm{N} 1$ & $30=\mathrm{N} 1$ \\
\hline Exractable K & cmolkg $^{-1}$ & $55=\mathrm{S} 2$ & $55=\mathrm{S} 2$ & $80=\mathrm{S} 1_{2}$ & $55=\mathrm{S} 2$ & $55=\mathrm{S} 2$ & $80=S 1_{2}$ \\
\hline Micro-nuts & $0.5 \mathrm{NHCl}$ & & & & & & \\
\hline Iron & & $15=\mathrm{N} 2$ & $45=\mathrm{S} 3$ & $45=\mathrm{S} 3$ & $15=\mathrm{N} 2$ & $45=\mathrm{S} 3$ & $45=\mathrm{S} 3$ \\
\hline Zinc & mgkg $^{-1}$ & $100=S 1$ & $100=\mathrm{S} 1$ & $100=\mathrm{S} 1$ & $100=\mathrm{S} 1$ & $100=S 1$ & $100=\mathrm{S} 1$ \\
\hline Manganese & & $65=S 2$ & $80=\mathrm{S} 1_{2}$ & $80=S 1_{2}$ & $65=S 2$ & $80=S 1_{2}$ & $80=\mathrm{S} 1_{2}$ \\
\hline $\begin{array}{l}\text { Actual } \\
\text { Suitability* }\end{array}$ & IPc & $5.74=$ & $5.26=$ & $5.26=$ & $3.10=$ & $9.26=$ & $8.78=$ \\
\hline $\begin{array}{l}\text { Potential } \\
\text { Suitability* }\end{array}$ & IPp & $21.04=$ & $21.06=$ & $17.55=$ & $11.36=$ & $37.05=$ & $29.25=$ \\
\hline $\begin{array}{l}\text { Actual } \\
\text { Suitability! }\end{array}$ & IPc & $8.55=$ & $6.53=$ & $6.53=$ & $4.07=$ & $10.08=$ & $9.55=$ \\
\hline $\begin{array}{l}\text { Potential } \\
\text { Suitability! }\end{array}$ & IPp & $28.37=$ & $26.12=$ & $21,77=$ & $11.91=$ & $36 ; 79=$ & $31.82=$ \\
\hline
\end{tabular}

Key: * - Suitability by Linear Model; ! - Suitability by Square Root Model; Land/Soil Xtics - Land and Soil Characteristics; Coarse Frag. - Coarse Fragments, Soil Phy. Prop. - Soil Physical Properties, Macro-nuts - Macro-nutrients and Micronuts - Micro-nutrients, IPp - index of potential productivity, IPc - index of current productivity 
Table.5: Qualitative Land Suitability Classes for the Different Land Indices

\begin{tabular}{lll}
\hline Symbol & Defination & Land Index \\
\hline S1 & Highly suitable & $75-100$ \\
S2 & Moderately suitable & $50-75$ \\
S3 & Marginally suitable & $25-50$ \\
N1 & Currently not suitable & $12.5-25.0$ \\
N1 & Permanently not suitable & $0.00-12.50$ \\
\hline
\end{tabular}

